\section{Antologi om medisinsk antropologi}

Helman CG, red.

Medical anthropology

580 s, tab, ill. Hampshire: Ashgate, 2008. Pris GBP 145

ISBN 978-0-7546-2655-8

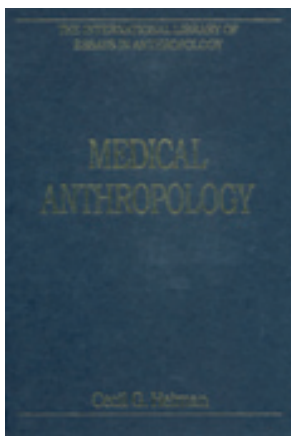

Medisinsk antropologi er et fagområde hvor man studerer kulturelle oppfatninger og atferd knyttet til årsaksforståelse, diagnostikk og håndtering av sykdom og helse i ulike sosiale grupper og samfunn. Innen fagfeltet er medisinsk kunn-

skap og praksis også gjenstand for studier og analyse. Faget har sterke tradisjoner i USA og Storbritannia og er etter hvert også blitt etablert ved flere europeiske universiteter, inkludert i Norge. Antologien Medical anthropology er redigert av Cecil G. Helman som er professor i medisinsk antropologi ved Brunel University i London. Helman er en av nestorene $\mathrm{i}$ faget, og Brunel University er kjent som det første europeiske universitetet som etablerte et eget masterstudium i medisinsk antropologi.

Å sette sammen en antologi om medisinsk antropologi er nødvendigvis en utfordrende jobb, bl.a. fordi det råder ulike oppfatninger om fagets egenart. En retning innen medisinsk antropologi retter for eksempel søkelyset mot sosial, kunnskapsmessig, politisk og økonomisk makt, og studerer hvordan slike forhold innvirker på helse og sykdom. En annen tilnærming er mer klinisk orientert, og siktemålet er å bidra til en bedre samhandling mellom behandler og pasient, enten på individ- eller gruppenivå. I innledningskapitlet skriver Helman oversiktlig om ulike perspektiver, og fastholder at fagfeltet er best tjent med å forbli flerfaglig: «It will need to remain an eclectic, multidisciplinary field of study, situated uncomfortably in the overlap between the natural and the social sciences».

Antologien, som stort sett består av tidligere publiserte artikler, er organisert i tre hoveddeler. Den første delen omhandler grunnleggende begreper og perspektiver, den andre anvendelse av antropologi innen klinisk arbeid og internasjonal helse, og den tredje nyere studier og teoridannelse knyttet til menneskekroppen. De 28 bidragene gjenspeiler et vidt spekter av forfattere og faglige ståsteder, og boken gir således innsikt i feltets tematiske og teoretiske bredde. Det vil alltid være mulig å peke på emner eller forfattere som burde ha vært med i en slik antologi. Helman har for eksempel ikke tatt med originaltekster av fremtredende medisinske antropologer som Nancy Scheper-Hughes, Margaret Lock, Paul Farmer og Arthur Kleinman. Enkelte av deres publikasjoner er imidlertid referert i innledningskapitlet.

Medical anthropology viser bredden $\mathrm{i}$ fagfeltet, men representerer ingen komplett tekstsamling. Antologien er en ressurs for forskere, masterstudenter i medisinsk antropologi og for spesielt interesserte. De fleste leger med interesse for å lære mer om skjæringsfeltet mellom kultur og sykdom vil nok i første omgang ha størst utbytte av å lese en ordinær lærebok. Det foreligger en god og oppdatert innføringsbok i medisinsk antropologi på norsk (1), og Helmans egen lærebok Culture, health and illness regnes som et internasjonalt standardverk (2).

\section{Jan C. Frich}

Institutt for allmenn- og samfunnsmedisin Universitetet i Oslo

\section{Litteratur \\ 1. Ingstad B. Medisinsk antropologi: en innføring. Bergen: Fagbokforlaget, 2007 \\ 2. Helman CG. Culture, health and illness. London:} Hodder Arbold, 2007.

\section{Tall som taler - men uten noe mer}

Verdens helseorganisasjon

Atlas of health in Europe

2. utg. 126 s, tab, ill. Genève: WHO, 2008. Pris CHF 14

ISBN 978-92-890-1410-6

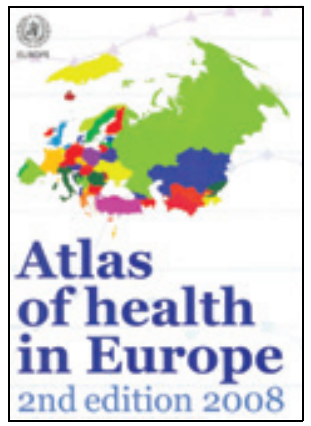

Andre utgave av Verdens helseorganisasjons atlas over helsetilstand og indikatorer på helsetjenester i Europa forteller en mektig historie på bare 126 sider uten særlig ordgyteri. På mange måter er dette et utgangspunkt for rik refleksjon hos leseren og illustrerer verdien av deskriptiv epidemiologi. Hva skyldes variasjonene mellom europeiske land? De kan da ikke være tilfeldige? De må ha en forklaring. Noe av variasjonen kan skyldes ulikheter i rapportering mellom landene, men forskjellene er for store og gjennomgripende til at dette holder som forklaring. En slik øvelse i å fortolke variasjon i helse og sykdom mellom befolkningsgrupper og over tid er en god måte å utvikle en kritisk sans for årsaker til sykdom i vid forstand. Variasjonen er ikke alene naturgitt.

Derfor kan denne boken brukes av mange. Selvsagt vil den passe for alle som i sitt virke må forholde seg til hvordan det står til i Norge sammenliknet med andre land i Europa. Det setter vår sykdomsbyrde $i$ et perspektiv. Men den kan også brukes $i$ undervisning hvor studenter eller unge forskere stimuleres til å foreslå forklaringer. En betydelig del av medisinsk forskning dreier seg om å finne gode forklaringer på variasjon av denne typen. Atlaset viser blant annet at dødeligheten av koronar hjertesykdom for dem under 65 år var nesten ti ganger høyere i Russland enn i Norge.

Dataene blir presentert på tre ulike måter: ved rangerte søylediagrammer, kart og ved linjediagrammer som viser utvikling over tid. Dessuten er landene delt inn i ulike områder, henholdsvis med lav og høy dødelighet. Så tar man for seg ulike helseområder, som demografi, dødelighet, sykelighet, livsstil og miljøfaktorer for det avsluttes med indikatorer på helsetjenester.

Det er problematisk at boken er såpass ordknapp. Innledningsvis er det to sider med en meget overfladisk beskrivelse av metodene som er brukt. Det holder vel ikke helt at man konstaterer at dataene ble samlet, validert og behandlet på en uniform måte for å sikre internasjonal sammenliknbarhet. Boken presenterer ulikheter i helse mellom befolkningsgrupper definert på nasjonalstatsnivå. Men man overser fullstendig sosial ulikhet innad i landene og omfanget av slik ulikhet på tvers av landene. Vi vet godt at omfanget av slik ulikhet er betydelig og her har WHO glemt seg. Til ross for disse innvendingene anbefales atlaset bredt fordi det gir et lett tilgjengelig og oppdatert kunnskapsgrunnlag av betydning.

\section{Øyvind Næss}

Divisjon for epidemiologi

Nasjonalt folkehelseinstitutt 